European journal of American studies

Special Issue: Transnational Approaches to North

American Regionalism

\title{
Introduction: Transnational Approaches to North American Regionalism
}

Florian Freitag and Kirsten A. Sandrock

\section{(2) OpenEdition \\ Journals}

Electronic version

URL: https://journals.openedition.org/ejas/10402

DOI: $10.4000 /$ ejas. 10402

ISSN: 1991-9336

Publisher

European Association for American Studies

Electronic reference

Florian Freitag and Kirsten A. Sandrock, "Introduction: Transnational Approaches to North American Regionalism", European journal of American studies [Online], 9-3 | 2014, Online since 23 December 2014, connection on 08 July 2021. URL: http://journals.openedition.org/ejas/10402 ; DOI: https://doi.org/ 10.4000/ejas. 10402

This text was automatically generated on 8 July 2021 .

Creative Commons License 


\section{Introduction: Transnational Approaches to North American Regionalism}

Florian Freitag and Kirsten A. Sandrock

In the past ten to fifteen years, critical understandings of regions and, concomitantly, regionalist approaches to literature and culture have undergone considerable changes. Studies such as Laurie Ricou's The Arbutus/Madrone Files (2002) or Claudia Sadowski-Smith's Border Fictions (2008), for instance, have focused on spaces and cultures that cross and crystallize around North American national borders, thereby questioning traditional, which is to say national, delineations of region. Even earlier, writers such as Gloria Anzaldúa (1987) redrew the boundaries of established concepts of region and nation, thus showing that what used to be seen as the fringes of North American literary and cultural studies could become the new center. In other areas, too, regional boundaries have come under critical scrutiny: for example, recent scholarship on both the U.S.-American West and the U.S.American South has tended to highlight the complexity, fluidity, and mobility of these spaces. In the preface to a special issue of American Literature on "Violence, the Body and "The South'" (2001), Houston A. Baker Jr. and Dana D. Nelson coin the term "new Southern studies" (231) and call for a "complication of old borders and terrains [as well as] wishes to construct and survey a new scholarly map of "The South'" (243). Numerous critics, including Martyn Bone, James L. Peacock, Scott Romine, and Michael Kreyling, have since taken up Baker's and Nelson's challenge, generally interrogating and deterritorializing the idea or myth of the U.S. South. As for the West, Susan Kollin, in Postwestern Cultures (2007), invites critics to work "against a narrowly conceived regionalism, one that restricts western cultures of the past and present to some predetermined entity with static borders and 
boundaries" (xi). Instead, she calls for "Postwestern studies," which "involve a critical reassessment of those [theoretical, geographical, or political] restrictions" (xi), with scholars such as Neil Campbell (Cultures, Rhizomatic West, Post-Westerns) or Krista Comer ("Exceptionalism," "Introduction") readily joining the debate.

2 Border(land) studies, New Southern studies, and Postwestern studies exemplify the shifting scholarly landscape in the field of regionalism towards more border-crossing, processual, pluralistic, and rhizomatic concepts of regions. ${ }^{i}$ They illustrate the newly emerging consciousness that neither borders nor literary and cultural regions are static and that the relations between them are complex. Indeed, borders and regions are recognized as being porous, changing constantly in the face of cultural mobility, and redrawing the cultural maps of North America on both a national and a transnational level.

This special issue of the European Journal of American Studies seeks to contribute to this development and to apply new theoretical approaches to regions as fluid imaginaries rather than static localities to various North American regions. The articles do so by considering regional writing and cultural productions in the light of transnational, hemispheric, and generally border-crossing contexts. As Krista Comer argues, it is now possible, thanks to a new diversity of theories and methodologies, to "figure regions and regionalism in far more comparative and multilingual ways" ("Taking Feminism" 117) than has traditionally been done. Similarly, Douglas Powell defines what he calls "critical regionalism" as an approach that, instead of focusing on how particular places are constructed through texts, asks what resources texts make available to understand and "recognize the dense networks of spatial relationships that intersect at any site on the landscape" (122). Already in 1996, Rob Wilson and Wimal Dissanayake noted that

the local need not embody a regressive politics of global delinkage, bounded particularity, and claims of ontological pastness, where locality becomes some backward-gazing fetish of purity to disguise how global, hybrid, compromised, and unprotected everyday identity already is. (5)

Transnational Approaches to North American Regionalism seeks to contribute to the exploration of how the global and the hybrid intersect with the local. We believe this is a more fruitful ground for examining North American literatures and cultures than ever.

\section{Regionalism in North American Studies}

5 Two main observations guide our conception of this special issue. First, we perceive that previous regionalist studies of North American literature and culture were predominantly concerned with aspects of national power. This is true for the political and economic debates about the permeability of the Mexican-U.S. border and the traditional blending of nationalist and regionalist discourses, for instance in Quebec, but first and foremost for the perceived dominance of 
nationalist discourses in the United States in contrast to (English) Canada's presumed preference for regionalist discourses. In both the United States and Canada, the region has frequently been understood as a counterpart to the nation. To anybody familiar with Canadian literature, Northrop Frye's famous distinction between the region and the nation will come to mind immediately. In his preface to Bush Garden (1971), Frye states that identity is "local and regional, rooted in the imagination and in works of culture" whereas unity is "national in reference...and rooted in a political feeling" (413). In Canada, then, the idea of the region has long been associated with identity and, more specifically, with literary and cultural identity. Scholars such as Herb Wyile (see Merrett), Gerald Friesen, and Lothar Hönnighausen ("Defining Regionalism") have used this alleged Canadian preference for regionalism to establish a contrast between the United States and Canada. Hönnighausen, for instance, notes that

North American Studies have the obvious advantage of entailing comparisons between the much more homogenized United States and the more regionalized Canada. The political culture of the United States, despite phases of sectionalism... has always been kept together by a strong homogenizing patriotic myth....In contrast, Canadians seem to experience their nationhood with diffidence and a shy sense of humor, the political reason for this being...the formidable impact of the regions vis-à-vis the much debated authority of Ottawa. ("Defining Regionalism" 173)

Statements such as this one draw a line between a supposedly more regionalist Canada and a supposedly more nationalized United States that is not only too static but that also risks perpetuating "the neglect of regionalism as a continuous tradition in American literary history" that Hönnighausen himself has lamented ("Defining Regionalism" 162). Yet regionalism cannot be confined to a given national space. If previous regionalist studies have tended to reduce North American regionalism not only to a binary nation-region dichotomy but also to a binary U.S.Canada dichotomy, then what is necessary today is a comparative perspective that offers an opportunity to consider regions, regional writing, and regionalism in contexts that transcend the nation or, rather, the national construct. In other words, what is necessary is a transnational perspective on North American regionalism, one that goes beyond the nation-region binary and allows us to take into consideration a variety of factors, both real and imaginary, in the construction of regions. Therefore, we would like to redress the reductionist view of North American regionalism as a counter to national power in favor of more heterogeneous and, we believe, more productive approaches to the nation-region relationship in North American literature and culture. Reminiscent of Gloria Anzaldúa's concept of the "mestiza consciousness" (see Anzaldúa), the articles gathered here illustrate how regionalist cultural and literary studies can be conceived of as empowering, pluralist discourses rather than as reductionist, dualist hegemonies. 
7 Secondly, we believe that border-crossing theoretical approaches to North American regionalism can help transcend the region-nation paradigm. These approaches include gender studies, Native Studies, borderland studies, ecocriticism/bioregionalism, and other methodological frameworks that facilitate the broadening of the scope of regionalist studies and the inclusion of previously marginalized voices. There have been a number of recent attempts to construct literary and cultural cross-border regions, not only but particularly in North America. Apart from Ricou's Pacific Northwest (see Ricou), one of the most prominent regions explored from this perspective is the Prairie/Plains region (see Thacker, Prairie Fact and "Erasing"), and also the border-crossing regions of North American writing that emerged in the context of the "local-color" movement (see Doyle; Gerson; Mount; and Lynch) and Chicano/Chicana literature (see Anzaldúa; MartínJunquera; Hamilton; and Hernández). In addition, gender and ethnicity studies, ecocriticism, comparative perspectives, and media studies have had an impact on the development of regionalisms. These methodologies point the way towards significant re-examinations of both regional writing and the critical category of the region in North America. With this special issue, we seek to contribute to this development and to develop new ways of thinking about regionalism and regional writing in Canada, Mexico, and the United States. Before we approach the essays of this issue, however, it is worth asking a key question: what exactly is a region?

\section{Changing Concepts of Region}

8 The concept of region has significantly changed over the years. Today, a variety of approaches to regionalism co-exist, but there is no single model or concept that critics agree upon. Traditionally, regions have been understood as geographical spaces that are characterized by a certain climate or by distinct topographical features. This approach towards regionalism, known as "formal regionalism," borrows its tools from the field of geography, and it is probably the way in which the term "region" is still understood by a majority of people today. Examples for this model of regionalism would be the Prairies or the Great Lakes region, but also the Rocky Mountains or the Pacific Rim, all of which are unified by some topographical feature(s). Despite its seeming obviousness, however, formal regionalism has been criticized because it largely leaves the human factor out of consideration. This is even true for formal approaches to literary regions, which have commonly seen landscape or topography as the defining feature of a given literary tradition. In The Great Prairie Fact and Literary Imagination (1989) Robert Thacker, for example, seeks to read prairie writing as being primarily characterized by "the landscape's effect on the human imagination" (53). "The great fact,'” Thacker notes, "has always been and is still "the land itself'" (9). Needless to say, such an 
approach reduces not only the region to its geographical features; it also reduces literature to a register of place.

9 As an alternative, scholars have proposed the so-called "structural" or "functional" approach to regionalism, where people and institutions play the most important role in identifying and researching individual regions. This means, for instance, that demographic factors-e.g. urban vs. rural regions-or political practices are taken into account when studying regions. Anyone familiar with U.S.-American politics will know that certain states have distinct voting habits, and that entire parts of the country can be clustered by their political alliances. Yet, while this formal approach to regionalism has the advantage of concentrating on humans instead of geographies, there is a danger of generalizing about the inhabitants of a location and, in so doing, devaluating their diversity. The example of voting habits serves as a good example: only because a majority of Californians traditionally votes for the Democratic Party, this does not mean that there are no Republicans living in the state. Thus, to group California as a Democratic state means to oversimplify its political structure and, hence, its internal diversity.

In order to remedy this oversimplification inherent in functional approaches to regionalism, there is a third perspective that is frequently taken to investigate the region in North America, and that is the one of "cultural" or "imaginary" regionalism. Here, the focus is also on the people, but not so much on their functional, i.e. operational behavior, but rather on their cultural and imaginary works and actions. Part of this approach is to look at the literature and culture of the people and to try to make out how creative productions have helped shape a region. The important point about this approach is that it assumes a reciprocal interaction between the cultural works and the region. Thus, if the images of Emily Carr are said to have been constructed upon the region of the Pacific Northwest and the people living there, then it could be equally said that the images have, in turn, helped construct the region and its people by means of their cultural impact on an international audience.

11 Yet, while this approach allows for diversity and difference, the question is in how far the recognition of a myriad of cultural productions allows for the identification of regions as critical concepts at all. Indeed, this is the question that has been frequently asked ever since the rise of postmodern and poststructuralist theories in the second half of the twentieth century. Is it still possible to conceptualize regions at a time when all unity or, indeed, identity is questioned for its alleged essentialism? Following this line of thought, one would have to reconsider the idea of regions and regionalist studies as a whole, just as one would have to reconsider any (theoretical) approach that seeks to find commonalities or points of comparison in literary and cultural studies in order to understand larger relations between people and places. 
12 This is precisely where, we think, transnational perspectives come into play. Transnational regionalism reads, and re-reads, regional texts from new perspectives while also adding new, previously marginalized texts to the debate. Thus, it enriches and diversifies the imaginary reservoir of a given region, destabilizing and deterritorializing received myths about and unified concepts of North American regions without necessarily doing away with the concept of region as such. Considering recent developments in the field of regionalist studies and North American studies, we are convinced that transnational regionalism constitutes a useful tool in the study of North American literature and culture in the post-postmodern era.

13 Transnational regionalism allows us to explore a variety of literary influences and cultural factors, including those mentioned abovephysical, human, cultural, and imaginary-without having to reduce a region to a single one of these factors or, indeed, to view it as a fixed concept in the first place. For this reason, this special issue offers a variety of transnational and border-crossing perspectives on North American regionalism and embraces different theoretical approaches, all of which contribute to the study of regions without trying to reduce them to a single essence. In fact, it might be more appropriate to speak about North American regionalisms rather than regionalism because this special issue features a multiplicity of methodologies and a diversity of regionalist concepts that enrich rather than replace each other.

\section{Transnational Perspectives on North American Regionalism}

The articles gathered here investigate regionalist borderlands by offering both case studies and theoretical examinations of transnational approaches to North America regionalism. The special issue opens with Caleb Bailey's essay "Creating a Coyote Cartography: Critical Regionalism at the Border." In this article, Bailey examines depictions of Coyote (the trickster) and coyote (the people smuggler) in the work of Thomas King and Charles Bowden in order to open up a theoretical and cultural dialogue between the Mexican-U.S. and the Canadian-U.S. borders. Two more contributions focus on borderlands: Steven M. Hoffman's, Paul Lorah's, and Joseph Janochoski's “Resisting the Inevitable: Tar Sands, Regionalism and Rhetoric" as well as Tereza Jiroutová Kynčlová's "Elastic, Yet Unyielding: The U.S.-Mexico Border and Anzaldúa's Oppositional Rearticulations of the Frontier." In the former, the authors analyze the dynamics, spatial distribution, and rhetorical frames used by a variety of networks whose opposition to the extraction and production of tar sands oil has necessitated developing across the 49th parallel. The latter essay contrasts Gloria Anzaldúa's rearticulation of the U.S.-Mexican border with established U.S. national 
myths of westward expansion and includes postcolonial and feminist readings of Anzaldúa's poem "We Call Them Greasers."

15 The second group of articles consists of two case studies that explore the transnational complexity of regionalism in cinema and photography. The first article provides an elegant transition from the first group since it also raises the issue of cross-border regions: in "'Somewhere in California': New Regional Spaces of Mobility in Contemporary Vancouver Cinema" Katherine A. Roberts examines two recent films by Vancouver auteur filmmaker Carl Bessai to discuss the emergence of what she calls a "regional space of flows" on the West Coast, a dual-city relationship between Los Angeles and Vancouver structured by the entertainment industry. Rachel Sailor's essay, entitled "'You Must Become Dreamy': Complicating Japanese-American Pictorialism and the Early Twentieth-Century Regional West," in turn, stresses the transPacific aesthetic connections in Western regional photography by focusing on the work of Seattle Camera Club member Kyo Koike, one of many Japanese-American pictorialist photographers in the Pacific Northwest during the first half of the $20^{\text {th }}$ century.

16 New Orleans, Cajun Country in southwest Louisiana, British Columbia, and the American Southwest are the "regions of identity" examined in the remaining four essays of this special issue. Amy Doherty Mohr's contribution, entitled "Down the River, Out to Sea: Mobility, Immobility, and Creole Identity in New Orleans Regionalist Fiction (1880-1910)," focuses on the geographical, social, and cultural (im)mobility of selected "transnational" characters in the work of George Washington Cable, Kate Chopin, and Alice Dunbar-Nelson. In "Migrating Literature: Zachary Richard's Cajun Tales," Mathilde Köstler explores the interrelation of Cajun culture and the transnational space in three francophone tales by Cajun singer/songwriter and author Zachary Richard. Using the poetic work of Daphne Marlatt as an example, Michelle Hartley's essay "Constructing a New Regionality: Daphne Marlatt and Writing the West Coast" develops "regionality" as a new way of capturing the intersection of geographical regions and writing from those regions by building on the notion of landscape as repository. Also dealing with poetry, the final essay in this special issue, Judith Rauscher's “On Common Ground: Translocal Attachments and Transethnic Affiliations in Agha Shahid Ali's and Arthur Sze's Poetry of the American Southwest," traces how the works of Ali and Sze imagine an ethics of being in and with nature that reckons with the increasing pressures of both globalization and the global environmental crisis.

The editors would like to thank the contributors for their stimulating essays and the peer reviewers for anonymously sharing their expertise. This special issue would not have been possible without the wonderfully reliable guidance of Marek Paryż and Andrew Gross, EJAS's Senior and Associate Editors for literature, culture, and the arts. Special thanks go to Lisa Schmidt, student assistant at Johannes Gutenberg University 
Mainz, for reliably supporting the editors during the copyediting process.

\section{BIBLIOGRAPHY}

Anzaldúa, Gloria. Borderlands/La Frontera: The New Mestiza. San Francisco: Aunt Lute Books, 1987.

Print.

Baker Jr, Houston A., and Dana D. Nelson. "Preface: Violence, the Body and 'The South." American Literature 73.2 (2001): 231-44. Print.

Bone, Martyn. The Postsouthern Sense of Place in Contemporary Fiction. Baton Rouge: Louisiana State UP, 2005. Print.

Campbell, Neil. The Cultures of the American New West. Edinburgh: Edinburgh UP, 2000. Print.

-. The Rhizomatic West: Representing the American West in a Transnational, Global, Media Age. Lincoln:

U of Nebraska P, 2008. Print.

-. Post-Westerns: Cinema, Region, West. Lincoln: U of Nebraska P, 2013. Print.

Comer, Krista. "Taking Feminism and Regionalism toward the Third Wave." A Companion to the Regional Literatures of America. Ed. Charles L. Crow. Malden, MA: Blackwell, 2003. 111-28. Print.

-. "Exceptionalism, Other Wests, Critical Regionalism." American Literary History 23.1 (2011): 159-73. Print.

-. "Introduction: Assessing the Postwestern." Western American Literature 48.1/2 (2013): 3-15. Print.

Crow, Charles L., ed. A Companion to the Regional Literatures of America. Malden, MA: Blackwell, 2003. Print.

Doyle, James. "Research-Problems and Solutions: Canadian Women Writers and the American Literary Milieu of the 1890s." Re(dis)covering Our Foremothers: Nineteenth-Century Canadian Women Writers. Ed. Lorraine McMullen. Ottawa: U of Ottawa P, 1990. 30-36. Print.

Freitag, Florian. "Regionalism in American and Canadian Literature." The Palgrave Handbook of Comparative North American Literature. Ed. Reingard M. Nischik. New York: Palgrave Macmillan, 2014. 199-218. Print.

Frey, Marc, Lothar Hönnighausen, James Peacock, and Niklaus Steiner, eds. Concepts of Regionalism. Madison: Center for the Study of Upper Midwestern Cultures, 2005. Print.

Friesen, Gerald. “The Evolving Meaning of Region in Canada.” Concepts of Regionalism. Ed. Marc Frey, Lothar Hönnighausen, James Peacock, and Niklaus Steiner. Madison: Center for the Study of Upper Midwestern Cultures, 2005. 101-17. Print.

Frye, Northrop. "Preface to the Bush Garden.” Northrop Frye on Canada. Ed. Jean O'Grady and David Staines. Toronto: U of Toronto P, 2003 [1971]. 412-20. Print. 
Gerson, Carol. “Canadian Women Writers and American Markets, 1880-1940.” Context North America: Canadian/US Literary Relations. Ed. Camille LaBossière. Ottawa: U of Ottawa P, 1994. 107-18. Print.

Hamilton, Patrick Lawrence. Of Space and Mind: Cognitive Mappings of Contemporary Chicano/a Fiction. Austin: U of Texas P, 2011. Print.

Hernández, Ellie D. Postnationalism in Chicana/o Literature and Culture. Austin: U of Texas P, 2009. Print.

Hönnighausen, Lothar. "Introduction.” Regional Images and Regional Realities. Ed. Lothar Hönnighausen. Tübingen: Stauffenburg, 2000. 7-13. Print.

-. "Defining Regionalism in North American Studies." Concepts of Regionalism. Ed. Marc Frey, Lothar Hönnighausen, James Peacock, and Niklaus Steiner. Madison: Center for the Study of Upper Midwestern Cultures, 2005. 159-84. Print.

Jordan, David M. New World Regionalism: Literature in the Americas. Toronto: U of Toronto P, 1994. Print.

-, ed. Regionalism Reconsidered: New Approaches to the Field. New York: Garland, 1994. Print.

Kollin, Susan. “Introduction: Postwestern Studies, Dead or Alive." Postwestern Cultures: Literature, Theory, Space. Lincoln: U of Nebraska P, 2007. ix-xix. Print.

Kreyling, Michael. The South Wasn't There: Postsouthern Memory and History. Baton Rouge: Louisiana State UP, 2010. Print.

Lynch, Gerald. "Short Fiction." The Cambridge History of Canadian Literature. Ed. Coral Ann Howells and Eva-Marie Kröller. Cambridge: Cambridge UP, 2009. 166-84. Print.

Martín-Junquera, Imelda, ed. Landscapes of Writing in Chicano Literature. New York: Palgrave Macmillan, 2013. Print.

Merrett, Robert James (chair). “What Is Region and Nation? A Forum.” Terranglian Territories: Proceedings of the Seventh International Conference on the Literature of Region and Nation. Ed. Susanne Hagemann. Frankfurt: Lang, 2000. 649-65. Print.

Mount, Nicholas J. When Canadian Literature Moved to New York. Toronto: U of Toronto P, 2005. Print.

Peacock, James L. Grounded Globalism: How the U.S. South Embraces the World. Athens, GA: U of Georgia P, 2007. Print.

Powell, Douglas Reichert. Critical Regionalism: Connecting Politics and Culture in the American Landscape. Chapel Hill: U of North Carolina P, 2007. Print.

Ricou, Laurie. The Arbutus/Madrone Files: Reading the Pacific Northwest. Corvallis: Oregon State UP, 2002. Print.

Riegel, Christian, and Herb Wyile, eds. A Sense of Place: Re-Evaluating Regionalism in Canadian and American Writing. Edmonton: U of Alberta P, 1998. Print.

Romine, Scott. The Real South: Southern Narrative in the Age of Cultural Reproduction. Baton Rouge: Louisiana State UP, 2008. Print.

Sadowski-Smith, Claudia. Border Fictions: Globalization, Empire, and Writing at the Boundaries of the United States. Charlottesville: U of Virginia P, 2008. Print. 
Sandrock, Kirsten A. Gender and Region: Maritime Fiction in English by Canadian Women, 1976-2005. Augsburg: Wißner, 2009. Print.

-. "Rethinking the Region in Canadian Postcolonial Studies." Zeitschrift für Kanada-Studien 31.2 (2011): 78-92. Print.

Thacker, Robert. The Great Prairie Fact and Literary Imagination. Albuquerque: U of New Mexico P, 1989. Print.

-. "Erasing the Forty-Ninth Parallel: Nationalism, Prairie Criticism, and the Case of Wallace Stegner." Essays on Canadian Writing 61 (1997): 179-202. Print.

Wilson, Rob, and Wimal Dissanayake. "Introduction: Tracking the Global/Local." Global/Local: Cultural Production and the Transnational Imaginary. Ed. Rob Wilson and Wimal Dissanayake. Durham: Duke UP, 1996. 1-18. Print.

Wyile, Herb. "Writing, Regionalism and Globalism in a Post-Nationalist Canada." Diverse Landscapes. Ed. Karin Beelar and Dee Horne. Prince George, BC: UNBC P, 1996. 10-18. Print.

\section{NOTES}

i. See also Crow; Freitag; Frey et al.; Sandrock, Gender and Region and "Rethinking." See additionally the work of critics such as David M. Jordan, Lothar Hönnighausen, and Herb Wyile, particularly Jordan, New World and Regionalism Reconsidered; Hönnighausen, "Introduction"; Wyile, "Writing"; and Riegel and Wyile.

\section{AUTHORS}

\section{FLORIAN FREITAG}

Johannes Gutenberg University Mainz

\section{KIRSTEN A. SANDROCK}

Georg-August University Göttingen 